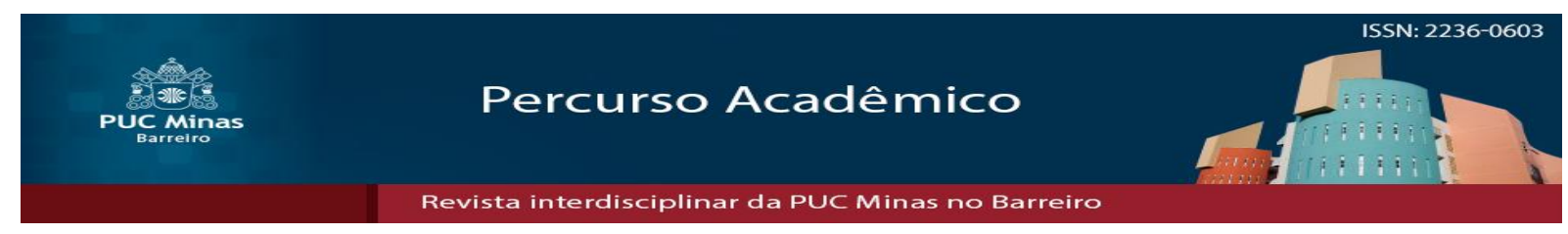

\title{
A banalização do impeachment no direito brasileiro e o efeito backlash
}

The banalization of the impeachment in brazilian law and the backlash effect

\section{RESUMO}

Matheus Henrique Braga de Morais ${ }^{1}$

O presente estudo tem vistas a analisar como se deu o processo de representação política e, consequentemente, a sua relação com as maneiras desenvolvidas pelas sociedades de responsabilização dos representantes políticos. $\mathrm{O}$ artigo se divide em três eixos centrais. $\mathrm{O}$ primeiro se dedica, para tanto, a apresentar a evolução do parlamentarismo e como se dá a responsabilização do Governo mediante a utilização da moção de censura ou voto de desconfiança. O segundo eixo apresenta as diferenças basilares existentes entre o instituto desenvolvido de forma efusiva nos Estados Unidos da América que é chamado de recall político, mecanismo que permite ao cidadão exercer de forma mais ampla e legitimamente democrática o seu direito político de representação e de voto, seja mantendo ou revogando um mandato. $\mathrm{O}$ terceiro eixo traz, de forma ampla, as bases fundamentais do impeachment no ordenamento jurídico brasileiro, apresentando as formas com que o Supremo Tribunal Federal, a Câmara dos Deputados e o Senado Federal se comportaram diante dos dois processos de impeachment a que a sociedade foi submetida. O objetivo principal do estudo se desenvolve dentro desse último eixo, demonstrando que o processo de impeachment foi banalizado a partir de 2015, servindo como subterfúgio para afastar autoridades constituídas pelo voto e na tentativa de sufocar e intimidar o exercício da jurisdição constitucional. Por fim, relata a defesa do Estado Democrático de Direito e a garantia da Supremacia da Constituição a partir da competência constitucional do Supremo Tribunal Federal e como as reações sociais por meio do backlash decorrem de movimentos antiestablishment em face das decisões judiciais proferidas e das políticas públicas desenvolvidas.

Palavras-chave: Moção de censura. Recall político. Banalização do Impeachment. Backlash.

\begin{abstract}
The present study aims to analyze how the process of political representation took place and, consequently, its relationship with the ways developed by societies of accountability of political representatives. The article is divided into three central axes. The first is dedicated, therefore, to present the evolution of parliamentarism and how the Government is held accountable through the use of the motion of censure or vote of no confidence. The second axis presents the basic differences that exist between the institute developed effusively in the United States of America which is called political recall, a mechanism that allows citizens to exercise their political right of representation and vote more widely and legitimately, whether maintaining or revoking a mandate. The third axis broadly presents the fundamental bases of impeachment in the Brazilian legal system, presenting the ways in which the Supreme Federal Court, the Chamber of Deputies and the Federal Senate behaved in the face of the two impeachment processes to which society was submitted. The main objective of the study develops within this last axis, demonstrating that the impeachment process was trivialized as of 2015 , serving as a subterfuge to remove authorities constituted by the vote and in an attempt to suffocate and intimidate the exercise of constitutional jurisdiction. Finally, it reports the defense of the Democratic Rule of Law and the guarantee of Supremacy of the Constitution based on the constitutional competence of the Supreme Federal Court and how the social reactions through backlash arising from anti-establishment movements in the face of judicial decisions and public policies developed, following the path by examining what the phenomenon is and its relationship with social discontent and impeachment.
\end{abstract}

Key-words: Censure motion. Political recall. Impeachment banalization. Backlash.

Artigo recebido em 05 de abril de 2021 e aprovado em 24 de maio de 2021

${ }^{1}$ Graduando em Direito pela Pontifícia Universidade Católica de Minas Gerais (PUC-MG). Atualmente integrante do Grupo de Estudos e Pesquisa em Direito Processual e Democracia PUC/MG, Brasil. E-mail: theushbraga@gmail.com 


\section{INTRODUÇÃO}

Os contornos históricos acerca da representação política são sementes para uma provocação mais afinca do íntimo liame entre o poder Constitucional pela Supremacia da Constituição para com o regime político idealizado pelos gregos e profetizado como "governo de todos", ora a democracia. Nessa esteira, o processo de construção de valores democráticos, sobretudo no ocidente, encontra respaldo e validade jurídica na expressão da vontade popular. Se em outrora Thomas Hobbes legitimou o poder do monarca ao exprimir o pensamento de que era necessária uma abdicação de desejos e depósito de legitimidade nas mãos de um único que faria fazer valer a lei, atualmente é o povo o mandatário desse poder conferido ao ente estatal que, em nome da coletividade, busca e perfaz a justiça.

É nesse sentido que se extrai, portanto, as palavras virtuosas de Andrade Junior (2010, p. 230), vejamos:

\footnotetext{
"No estado de direito democrático, o poder político emana do povo que é o legitimado para construir e validar as normas jurídicas. O próprio povo é principal destinatário do direito, pois a pessoa natural deve-ser promotora de dignidade para si para os outros. Assim, também todas as pessoas jurídicas devem ser agentes promotoras de dignidade humana.".
}

Por essa razão, a legitimidade que a coletividade deposita ao ente estatal não poderá ser transferida nos moldes de um contrato social como idealizou Rousseau e o próprio Hobbes, mas, diante da nova ordem democrática, será sim conferido e efetivado através da participação direta do povo no processo de decisão e por meio das estruturas de poder democraticamente constituídas. Insurge, portanto, um sistema político eficaz para parte da sociedade que, através do poder da cidadania, consagra a participação popular.

A partir de 2015 quando o então presidente da Câmara dos Deputados, Eduardo Cunha, a partir da acusação apresentada por Hélio Bicudo, Miguel Reale Júnior e Janaina Paschoal decide pela abertura do processo de impeachment da então Presidente Dilma Rousseff, pedidos como esse passaram a se tornar comuns. Vale ressaltar que no Brasil o impeachment é a única maneira pela qual um Presidente da República e seu Vice-Presidente podem ser retirados do cargo para os quais foram democraticamente 
eleitos, e está previsto no Brasil, de certa forma, desde a Constituição imperial de 1824 e na história moderna republicana somente foi utilizado duas vezes.

Notadamente, o impeachment é previsto na Constituição da República em seu art. 52 dentre as competências privativas do Senado Federal de processar e julgar nos crimes de responsabilidade, por exemplo, o Presidente da República, os ministros de Estado, os ministros do Supremo Tribunal Federal, o Procurador-Geral da República e outras autoridades e é regulamentado pela Lei $\mathrm{n}^{\mathrm{o}}$. 1.079/50.

A problemática surgida, entretanto, caminha pelos campos de que pós-2015 os pedidos de impeachment Brasil afora acabaram se tornando instrumento político pelo qual a sociedade e parlamentares descontentes passaram a tentar destituir o Presidente da República, Governador, Prefeito, além de corriqueiramente atingir ministros do Supremo Tribunal Federal.

Este trabalho, portanto, tem vistas a desenvolver um breve estudo acerca da banalização do instituto quanto à figura da responsabilização política do Presidente da República, diferenciando-a quando exercida no voto de desconfiança no parlamentarismo ou no recall político e, também, é voltado para a análise dos pedidos de impeachment referentes a ministros do Supremo Tribunal Federal em preclara decorrência do efeito backlash quanto às decisões individuais e coletivas proferidas pela Corte como resposta do movimento antiestablishment.

Dessa forma, o objeto de estudo perseguido se forma a partir de pesquisa estritamente bibliográfica e tem por finalidade contribuir para o conhecimento dos pesquisadores e alunos de pós-graduação, não implicando em transformações sociais reais, posto ser de natureza qualitativa e dedutiva no que tange ao método escolhido.

\section{O VOTO DE DESCONFIANÇA E O PARLAMENTARISMO}

Diferentemente do impeachment e do recall, conforme se verá posteriormente, o voto de desconfiança guarda relação estritamente com os sistemas parlamentaristas de governo, tendo em vista a necessária separação entre as figuras dos Chefes de Estado e de Governo.

No parlamentarismo a responsabilidade política em sentido lato, ou seja, a necessidade de tomar uma decisão que mudaria por completo os rumos da sociedade encontram seus primórdios nos longínquos anos que precederam a invasão normanda na Inglaterra no século XI. O reino inglês, à época, por exemplo, possuía uma instituição denominada de witan em que comumente aconselhava o monarca nas decisões e seus 
componentes gozavam de inteiro prestígio social por serem membros da alta sociedade. Com a invasão no século XI, o witan foi substituído pela curia regis, que basicamente "possessed every attribute which has been ascribed to it. It was the executive. It was also a Law Court. It certainly took part in acts of legislation.” (DICEY, 1887, p. 7).

Com a manutenção da dominação normanda e os anos que sucederam, o Conselho real passou a ganhar notoriedade e independência, discutindo cada vez mais a atuação real por meio dos nobres, fiscalizando desde assuntos militares até a arrecadação dos impostos. Neste meio tempo, os nobres do Conselho, apoiados por outros tantos, acabam impondo ao monarca a Magna Charta Libertatum em 1215.

Gradativamente, a história monárquica inglesa com o passar dos séculos e as constantes transformações sociais acaba se adequando quando o Parlamento do Reino Unido é estabelecido em aspectos similares aos conhecidos hoje em dia através do Ato da União de 1800, entretanto, há parcela da doutrina que entende que o Parlamento somente se formou e tomou seu lugar de destaque quando a Câmara dos Comuns é instituída e o sistema representativo é instaurado ao final do século XIX (BONAVIDES, 2015, p. 343).

Em posição contrária à formação do parlamentarismo, Alexandre de Moraes (2004, p. 19 e ss.) aponta que o Parlamento ascende quando da Revolução Gloriosa em 1688, ano em que foi assinado o bill of rights que introduziu a separação dos poderes executivo (Coroa) e legislativo (Parlamento), lançando as bases de um modelo de freios e contrapesos.

Importante ressaltar que o Poder Executivo no sistema parlamentarista é dual, ou seja, não é concentrado em apenas uma figura como no presidencialismo, pois ele se divide entre a figura do monarca ou do Presidente da República que representam a chefia de Estado e entre o primeiro-ministro ou Chanceler que abarcam a chefia de Governo. Para Paulo Bonavides (2015, p. 216), "nele os monarcas e presidentes reinam ou presidem, mas não governam, porque o governo todo é obra do gabinete, designadamente do primeiro-ministro", dessa forma ele - o primeiro-ministro, neutraliza "a figura do Chefe de Estado, habitualmente desfalcado de faculdades ativas e mero representante ou símbolo da unidade do poder ou da nação.”.

A partir da institucionalização do poder legislativo com a existência do modelo bicameral inglês, fundado na Câmara dos Lordes e na Câmara dos Comuns, bem como a descentralização do poder executivo na figura do primeiro-ministro encabeçando o gabinete do rei, a discussão passou para como se daria a responsabilização do governo, 
diferentemente do que ocorreu com a Revolução Inglesa quando Oliver Cromwell depôs o rei Carlos I e o decapitou, depois passou a governar com mãos de ferro.

Segundo Paulo Bonavides (2015, p. 344), os ministros do governo que então fossem retirados do poder "ficariam sujeitos a um processo de responsabilidade, em que caberia a acusação à Câmara dos Comuns e o julgamento à Câmara dos Lordes.”, em processo bastante similar ao que se vê no Brasil em que a Câmara dos Deputados acolhe a denúncia e remete para o Senado Federal que fará novo juízo de admissibilidade para então processar e julgar. Ou seja, nascia no direito inglês o impeachment.

Todavia, a ritualística do processo de impeachment perante ao direito inglês regido pelo commom law acabou levando tal instituto para o ostracismo jurídico, caindo em claríssimo desuso em razão da "constante colaboração entre o Legislativo e o Executivo, tratando de equilibrar suas autoridades pelos chamados votos ou moções de censura ou desconfiança, formulados pelo Parlamento e o Poder de dissolução do Parlamento pelo Chefe de Estado". (CRUZ, 1998, p. 40). Assim

a outorga da confiança política da Nação mantém os governos no poder por via do instituto da responsabilidade ministerial. A moção de confiança pode em todas as ocasiões de crise renovar ou recusar o apoio parlamentar de que depende a conservação dos gabinetes. (BONAVIDES, 2015, p. 217).

Dessa forma, o parlamentarismo acaba por incentivar que o Governo negocie com o Parlamento, levando em consideração que a sua existência depende dele e da consequente manutenção da maioria entre os parlamentares, diferentemente do que é previsto no presidencialismo em que a saída da base governamental não pressupõe que o governo será destituído, ou ao menos não deveria (STEPAN, 1990, p. 103 e 105).

Assim, o voto de não confiança ou de desconfiança ou moção de censura é o instrumento pelo qual o Parlamento busca entender se os atos do Poder Executivo se coadunam com o interesse público que ele representa, obviamente baseado em seus aspectos políticos e de suas conveniências. Trata-se, assim, de meio de forçar a demissão dos integrantes do Governo por meio de "proposta parlamentar, manejada pela oposição, que visa derrotar ou constranger o governo e que tem como fundamento a contradição da posição por este adotada em desfavor do interesse público." (COUTINHO, 2013, p. 8109). 
O efeito básico da aprovação da moção de censura ou voto de desconfiança ou de não confiança implica na imediata dissolução do Governo, não necessariamente decorrente da prática de algum crime de responsabilidade na esfera infraconstitucional ou de algum atentado contra a ordem constitucional vigente, como é o sustentáculo do impeachment, mas tem seu nascedouro em crises eminentemente políticas como foi o caso da moção de censura lançada pelo Partido Trabalhista contra a primeira-ministra britânica, Theresa May, em razão das sucessivas derrotas no Parlamento em relação aos acordos feitos para formalizarem o Brexit, processo de saída da União Europeia.

Impende registrar que como no sistema parlamentarista o Governo nasce a partir do Parlamento e partindo da premissa de que o Governo sempre deve prestar contas ao povo (accountability) e o povo reunido, em regra, é o Parlamento, a quebra da confiança depositada é que acaba possibilitando aos parlamentares lançarem mão de tal ferramenta, acarretando a demissão dos integrantes do Gabinete encabeçado pelo primeiro-ministro convidado pelo rei a formar um governo em seu nome ou nomeado pelo Presidente da República.

Por essa razão, o voto de não confiança não comporta os aspectos de dramaticidade inerente ao impeachment, sendo mecanismo parlamentar que pode ser usado a qualquer tempo e desvencilhado da necessidade de comprovação de crime de responsabilidade que o fundamente, ou seja, é saída menos traumática para o amadurecimento democrático no âmbito do parlamentarismo.

\section{O RECALL POLÍTICO COMO CONTRAPONTO AO IMPEACHMENT}

Cuida-se de hipótese de revogação de mandato eletivo com bases diversas da do impeachment, distanciando-se da necessidade única da comprovação de crime de responsabilidade pelo governante, mas diferindo-se, em especial, à causa de sua instauração que caminha pela perda da representatividade e do apoio da população em geral.

Cumpre destacar que inexiste uma palavra no vernáculo português que substitua a palavra em sua forma inglesa. Segundo o dicionário bilíngue prático (2008, p. 358), recall é "revogação; lembrança; recordação; chamada.". Recall, na prática, tem mais proximidade com as relações consumeristas que envolvem a chamada dos consumidores pelos fornecedores de bens para corrigirem problemas na fabricação, exemplo mais que corriqueiro são as fábricas de automóveis anunciando recall de seus veículos. 
A natureza jurídica do recall, entretanto, parece não trazer dúvidas sobre seu status perante a Constituição de expressão da soberania popular, além de elemento constituidor da dignidade da pessoa humana através da participação popular no processo de escolha dos representantes políticos. Se nos debruçarmos sobre a Declaração Universal dos Direitos Humanos de 1948 perceberemos que ela e a própria Constituição de 1988 consagram como elemento intrínseco da liberdade e da dignidade da pessoa humana a participação direta do povo no limiar das escolhas políticas.

Tanto assim o é, que muitos Estados nos Estados Unidos da América já aderiram ao recall como meio alternativo ao impeachment, que passou a ser verdadeiro instrumento de medição da correspondência entre as decisões dos representantes eleitos e o interesse público. Segundo lição de Dalmo Dallari (2000, p. 155), o recall é um instituto do direito público norte-americano

\footnotetext{
que tem aplicação em duas hipóteses diferentes; ou para revogar a eleição de um legislador ou funcionário eletivo, ou para reformar decisão judicial sobre constitucionalidade de lei. No primeiro caso, exige-se que um certo número de eleitores requeira uma consulta à opinião do eleitorado, sobre a manutenção ou a revogação do mandato conferido a alguém, exigindo-se dos requerentes um depósito em dinheiro. Em muitos casos dá-se àquele cujo mandato está em jogo a possibilidade de imprimir sua defesa na própria cédula que será usada pelos eleitores. Se a maioria decidir pela revogação esta se efetiva. Caso contrário, o mandato não se revoga e os requerentes perdem para o Estado o dinheiro depositado.
}

A estrutura acima demonstra a profundidade com que o instituto permeia as noções jurídicas do direito estadunidense, vez que, não só para políticos, serve para revogar eleição de funcionário ou reformar decisão judicial que verse sobre constitucionalidade de lei, em claro combate ao instituto do judicial review consagrado no direito norte-americano com o julgamento do caso Marbury v Madison pela Suprema Corte dos Estados Unidos em 1803, ou seja, quando restou assentada a possibilidade do controle judicial por qualquer juiz ou tribunal da constitucionalidade de atos exarados pelo poder público e leis promulgadas pelo parlamento.

$\mathrm{Na}$ história recente norte-americana, por exemplo, destaca-se a aplicação do instituto do recall na eleição que fez com que o ator austro americano Arnold Schwarzenegger fosse alçado ao cargo de governador do estado da Califórnia em 2004, 
com a destituição do governador Gray Davis em razão da perda de sua popularidade, mas que havia sido reeleito em 2002. Aspecto importante a ser trazido é a forma com que o recall é aplicado no estado da Califórnia, em que

o eleitorado vota primeiramente sobre a destituição ou não do agente público e, posteriormente, vota-se em quem deverá substituí-lo. Ambos os votos são expressos na mesma cédula e o agente que está sofrendo o recall não participará como candidato. Nesta forma, se o agente público conseguir maioria na primeira votação continuará no cargo e a segunda votação será desconsiderada, consequentemente. (NATO; BAUAB, 2019, p. 443).

No Brasil, em aspecto diametralmente contrário, antes mesmo da abertura do processo de impeachment em 2015, foi apresentada a Proposta de Emenda à Constituição nº 21/2015 e que contou com parecer favorável do relator, Senador Antônio Anastasia, à época do PSDB/MG, limitando a sua utilização apenas para revogação do mandato do Presidente da República.

Segundo o relator, já diante os inúmeros pedidos de impeachment que chegavam à Câmara dos Deputados contra o presidente em exercício Michel Temer, bem como contra prefeitos e governadores nas respectivas casas legislativas competentes, a iniciativa de restringir o instituto

representa uma solução de equilíbrio entre a concretização do princípio da soberania popular e a responsabilidade, evitando-se o risco de a revogação ser utilizada como mero instrumento de instabilidade política (risco esse já apontado por diversos autores: cf. SERDULT, Üwe. The history of a dormant institute. Norms and practices of recall in Switzerland. In: Representation, 51:2, p. 161) (SENADO FEDERAL, 2017, p. 4).

Assim, a Constituição passaria a vigorar com a inclusão do art. 86-A, que disporia e regularia a matéria sobre a revogação do mandato presidencial e a inclusão do $\S 3^{\circ}$ ao art. 28 que permite aos Estados e ao Distrito Federal promover alterações legislativas acerca da questão.

Art. 86-A. O mandato do Presidente da República poderá ser revogado, mediante proposta subscrita por eleitores em número não inferior a um décimo dos que compareceram à última eleição presidencial, distribuídos por 
pelo menos quatorze Estados, cada um deles com não menos de cinco por cento dos eleitores que votaram no referido pleito.

$\S 1^{\circ}$ A proposta de revogação será apreciada pela Câmara dos Deputados e pelo Senado Federal, sucessiva e separadamente, e considerada aprovada se obtiver o voto favorável da maioria absoluta dos membros de cada uma das Casas.

$\S 2^{\circ}$ Aprovada a proposta de revogação, será convocado referendo, na forma do inciso XV do art. 49, para ratificá-la ou rejeitá-la.

$\S 3^{\circ}$ Revogado o mandato, será declarado vago o cargo de Presidente da República, aplicando-se o disposto no art. 79.

$\S 4^{\circ}$ É vedada proposta de revogação durante o primeiro e o último ano do mandato.

$\S 5^{\circ}$ É vedada a apreciação de mais de uma proposta de revogação por mandato.

Entendemos, dessa forma, que se trata de verdadeiro instrumento democrático e legitimador da soberania da vontade do povo que permite que o mesmo eleitorado que conferiu o mandato eletivo, possa revogá-lo quando as diretrizes políticas estejam em dissonância com relação àquilo que levou o candidato a lograr êxito em sua campanha. Ou seja, quando o eleitorado perceber se tratar de um político incompetente, corrupto, inoperante ou irresponsável.

Nesta seara, por exemplo, Daniela Romanelli (2005, p. 207) considera que "a revogação de mandato é um direito político originário, porquanto permite que o conjunto de cidadãos impeça que um mandatário que não cumpre a sua função a contento permaneça no poder”. Alexandre de Moraes (2016, p. 246) aduz implicitamente que o referido direito político originário abarca desde a capacidade de eleger alguém, como de ser eleito e de participar da atividade do poder estatal.

Conforme ensinamento doutrinário o direito político constitui "direito público subjetivo democrático e fundamenta-se no princípio da soberania popular", pois, "no Estado Constitucional, não se concebe poder do Estado que não esteja assentado na soberania popular e na dignidade humana, consequentemente.” (NERY JR; ABBOUD, 2019, p. 510 e 539).

Por fim, diferentemente do impeachment que tem consigo uma carga muito forte de responsabilização, vez que necessita da comprovação de um crime de responsabilidade e possui como consequência a perda dos direitos políticos, o recall busca responsabilizar o representante eleito unicamente por suas falhas no exercício da 
administração pública, fazendo com que ele também esteja sempre buscando mecanismos de prestação de contas (accountability) para a sociedade.

\section{A BANALIZAÇÃo DO PROCESSO DE IMPEACHMENT NO DIREITO BRASILEIRO E O EFEITO BACKLASH DECORRENTE DO MOVIMENTO ANTIESTABLISHMENT}

O processo de impeachment é de natureza eminentemente política e tem como fim precípuo a apuração, o processamento e o julgamento dos crimes de responsabilidade cometidos pelo Presidente da República, ministros de Estado, do Supremo Tribunal Federal, entre outros. Tem também natureza sancionatória, visto que em decorrência do impeachment será declarada a perda do cargo e, nos termos do art. 52, parágrafo único, da Constituição da República, ficará inabilitado por 8 (oito) anos para o exercício de funções públicas.

A Constituição, para além dos crimes de responsabilidade que pode incorrer o Presidente da República (vide art. 85), possui previsão de outros crimes de responsabilidade a que estão sujeitos, por exemplo, os prefeitos e os presidentes das câmaras municipais (art. 29, $\S 1^{\circ}$ e $\S 3^{\circ}$ ); os ministros de Estado no caso de serem convocados pelo Congresso Nacional e não comparecerem sem justificativa adequada, bem como não fornecerem informações por escrito quando assim for encaminhado pela Câmara Federal e pelo Senado (art. 50, caput c/c $\$ 2^{\circ}$ ); no caso de um Presidente de Tribunal retardar ou tentar frustrar o pagamento de precatórios (art. 100, §7 ${ }^{\circ}$; dentre outras previsões no texto constitucional e que são subsidiadas por aquelas constantes da vulgarmente conhecida como Lei do Impeachment (Lei $\mathrm{n}^{\circ}$. 1.079/50)

Quando do julgamento da Arguição de Descumprimento de Preceito Fundamental 378, o plenário do Supremo Tribunal Federal reassentou os papéis constitucionais tanto da Câmara dos Deputados quanto do Senado Federal, aclarando que o rito a ser seguido deve se espelhar não na Lei $\mathrm{n}^{\circ}$. 1.079/50, mas perante as competências privativas que a Constituição incumbiu a cada Casa, em se tratando de processo de impeachment contra o Presidente, o Vice-Presidente e os Ministros de Estado (art. 51, I, CR/88).

Segundo o julgado, "a Câmara exerce, assim, um juízo eminentemente político sobre os fatos narrados, que constitui condição para o prosseguimento da denúncia. Ao Senado compete, privativamente, processar e julgar o Presidente (art. 52, I)" (BRASIL, 
2016, p. 3), podendo e devendo, inclusive, ao Senado, a realização de juízo de admissibilidade sobre a instauração ou não do processo.

Por essa razão é que se costuma dizer que o julgamento perante o Senado Federal é bifásico, possuindo i) juízo de pronúncia, em que haverá a decisão quanto à admissibilidade ou não da denúncia recebida pela Câmara. Logo, não há subordinação entre a decisão da Câmara Federal em autorizar a remessa da denúncia para o Senado Federal e ele obrigatoriamente instaurar o processo e ii) juízo da causa, em que o Senado, constatando a verossimilhança das alegações processará e julgará o Presidente da República, o Vice-Presidente e os Ministros de Estado.

No que concerne ao item “i” acima, a doutrina caminha para o mesmo entendimento e que particularmente comungamos, senão vejamos:

\footnotetext{
A redação do art. 51, I da $\mathrm{CF}$, diz que à Câmara compete autorizar instauração do processo. O Verbo denota permissão. Afirmar que, por decisão da Câmara, o Senado está autorizado a instaurar o processo de impeachment contra o Presidente da República é diferente de assevera que está obrigado a fazê-lo. (NERY JR. ABBOUD, 2019, p. 724).
}

Pronunciado então pelo Senado Federal, ou seja, recebida a denúncia, constatado pelos senadores que a acusação encontra fundamento, o Presidente da República será afastado do cargo pelo período de 180 (cento e oitenta) dias improrrogáveis, sendo que ao fim do prazo poderá ser reintegrado às suas funções, conforme dispõe o art. $86, \S 1^{\circ}$, II, da CR/88.

A fim de prestigiar o devido processo constitucional, garantir a observância ao contraditório e à ampla defesa, quando do julgamento do impeachment do ex-presidente Fernando Collor e estendido ao julgamento da ex-presidente Dilma Rousseff, o Supremo Tribunal Federal entendeu que é dado ao acusado o direito de se defender das acusações no prazo de 10 (dez) sessões enquanto perdurar a fase de delibação.

Perceba-se que a expressão "devido processo constitucional”, muito embora o texto constitucional e a redação do acórdão fale expressamente em "devido processo legal”, em razão da leitura constitucional de todo o ordenamento jurídico pátrio e da adoção pelo Brasil do sistema romano-germânico-canônico denominado civil law, em que a validade, a eficácia e a legitimidade da aplicação da lei decorre da observância aos princípios da reserva legal, da legalidade, do contraditório e da ampla defesa, não a 
partir somente da convicção valorada do julgador, entendemos que as garantias processuais não observarão o processo decorrente de lei, mas o ordenamento jurídico pátrio avalizará, anunciará, declarará e assegurará o "devido processo resultante da práxis constitucional", ainda que o processo seja eminentemente político.

Como se pode perceber o processo de impeachment é extremamente burocrático e moroso, o que acaba acarretando em ser uma solução traumática, pois basicamente o Parlamento passa a se debruçar unicamente sobre o processo e as alianças que são construídas - seja no sentido de levar até às últimas consequências o processo, seja no caminho de sepultá-lo o quanto antes.

Conforme já amplamente noticiado no presente trabalho, o impeachment não guarda relação com a moção de censura/voto de desconfiança/voto de não confiança próprio do sistema parlamentarista, vez que necessita da dissociação da figura do Chefe de Estado e de Governo e a vinculação deste último ao Parlamento para a prestação de contas (accountability).

Tampouco se aproxima daquilo que é conhecido como recall político pela doutrina e que é objeto de Proposta de Emenda à Constituição pelo Senado Federal. Enquanto um reforça a soberania popular através da fiscalização das ações de seus escolhidos, podendo optar diretamente pela revogação ou manutenção do mandato eletivo; o outro reforça a ideia de democracia representativa indireta e que recai sobre um órgão legislativo, que demanda a constatação de um ilícito.

Todavia, o que se tem percebido é que mesmo diante da imensa diferença jurídica entre os institutos, muitos têm preferido lançar mão do impeachment como ferramenta de revogação de mandato eletivo em razão de descontentamento pelas políticas implementadas ou utilizando como ferramenta para tentar destituir Ministros dos Tribunais superiores, tal como os do Supremo Tribunal Federal, pelos votos proferidos no exercício da judicatura.

Ou seja, se determinada política pública voltada para o desencarceramento em massa de condenados por crimes sem violência, muitas vezes insignificante, que vá contra determinados valores de um determinado grupo, mas que não atente contra direitos e garantias fundamentais e a Constituição em si, ou uma decisão judicial que tenha o mesmo entendimento (cf. STJ, HC 596.603/SP) e que vá contra aquilo que acredita o cidadão comum, não são exemplos de crimes de responsabilidade capazes de respaldar a instauração de um processo de impeachment, ainda que o seu autor seja um Presidente da República que não goze de apoio popular amplo, ainda menos que seja 
Ministro do Supremo Tribunal Federal ou do Superior Tribunal de Justiça no exercício de seu mister na defesa da supremacia da Constituição.

Nessa seara, portanto, o que se tem é um preclaro movimento antiestablishment que desaguará na ocorrência do efeito backlash, seja contra o Presidente da República, seja contra os juízes constitucionais. Ou seja, a movimentação dos setores que são contrários às políticas implementadas ou contra as decisões judiciais proferidas pelo órgão de cúpula do Poder Judiciário, sublevarão parcela da sociedade civil e é esse, basicamente, o sentido do efeito backlash.

Vale dizer que ele não se trata tão somente de um descontentamento social que desemboca em balbúrdia, mas pode ser, também, o natural discutir de ideias a partir de decisões ampla e fartamente fundamentadas do ponto de vista jurídico e metajurídicos, mas é também "uma importante sinalização de opinião que, ao fim e ao cabo, emanaria do verdadeiro legitimado à interpretação constitucional: o povo." e, ainda, como sendo um ambiente natural "de discussões travadas em um Estado Democrático de Direito, fundado no pluralismo de ideias contrapostas." (FONTELES, 2019, p. 43), a fim de garantir o aprimoramento do ordenamento constitucional.

A doutrina ensina que:

o backlash costuma nascer de decisões que solucionam desacordos morais, portanto, de temas que dividem o sentimento social. Porém, essa divisão costuma ser desigual, sendo bastante frequente que exista uma opinião pública predominante, ainda que nem sempre seja tarefa simples decifrá-la. É exatamente dessa fração social incomodada pela decisão que, em geral, a reação política se origina. (FONTELES, 2019, p. 70).

Ainda segundo Fonteles (2019, p. 73), “o backlash não se confunde com a mera opinião pública desfavorável a um julgado", todavia "tem-se uma verdadeira revolta social que se exprime por atos estratégicos destinados a enfraquecer ou mesmo superar a decisão hostilizada". Ou seja, não é dizer que somente o descontento de um representante de determinado grupo social em mídia social caracteriza-se o backlash, mas é necessário que haja revolta popular.

Segundo Robert Post e Reva Siegel, "backlash expresses the desire of a free people to influence the content of their constitution, yet backlash also threatens the Independence of law. Backlash is where the integrity of the rule of law clashes with the need of our constitutional order for democratic legitimacy" (p. 390.). Entretanto, para os 
próprios teóricos, o efeito backlash por ser um fenômeno da reivindicação a partir da pressão feita em autoridades públicas, bem como das reações hostis que costuma ocorrer, tem um preço alto a ser pago.

No caso do efeito backlash que desagua em um processo de impeachment do Presidente da República, o preço a se pagar é a instabilidade política, econômica e social que poderá se seguir nos meses em que perdurar o processo, porquanto como já dito o Parlamento será tomado pelo funcionamento das comissões e da formação de alianças, enquanto projetos de lei e outras políticas públicas ficarão lançados ao segundo plano.

No que tange o impeachment de um ministro do Supremo Tribunal Federal, as hipóteses do crime de responsabilidade não são tão amplas quanto àquelas insculpidas no art. 85 da Carta Fundamental, são restritas, basicamente, àquelas previstas no rol do art. 39 da Lei $\mathrm{n}^{\circ}$. 1.079/50. O que se depreende é que pedidos de impeachment formulados neste campo possuem como pano de fundo tão somente a insatisfação para com a decisão judicial proferida pelo STF e busca, na tentativa de se afastar do seu dever de prestação de contas ao seu eleitorado (accountability), lançar uma cortina de fumaça ao atacar instituições que servem para a defesa do Estado Democrático de Direito.

Georges Abboud, com a sapiência que lhe é própria, assim aduz:

Defender a jurisdição constitucional é proteger uma instituição crucial para a democracia. Daí ser fundamental a despoluição semântica. A banalização de pedidos de impeachment que temos vivenciado não é uma reação legítima do Legislativo em face de erros da jurisdição constitucional. Trata-se, na realidade, de ataque institucional feito por alguns parlamentares contra a jurisdição constitucional, apenas porque discordam de teor dos seus votos, e não porque apontam crimes na conduta dos ministros do STF. (2021).

Neste sentido, a jurisprudência do Supremo Tribunal Federal é de clareza irrefutável quanto aos aspectos constitutivos da jurisdição constitucional, vejamos:

COMISSÃO PARLAMENTAR DE INQUÉRITO - QUEBRA DE SIGILO BANCÁRIO, FISCAL E TELEFÔNICO - AUSÊNCIA DE INDICAÇÃO DE FATOS CONCRETOS - FUNDAMENTAÇÃO GENÉRICA INADMISSIBILIDADE - CONTROLE JURISDICIONAL POSSIBILIDADE - CONSEQÜENTE INVALIDAÇÃO DO ATO DE 
"DISCLOSURE" - INOCORRÊNCIA, EM TAL HIPÓTESE, DE TRANSGRESSÃO AO POSTULADO DA SEPARAÇÃO DE PODERES MANDADO DE SEGURANÇA DEFERIDO. A QUEBRA DE SIGILO QUE SE APÓIA EM FUNDAMENTOS GENÉRICOS E QUE NÃO INDICA FATOS CONCRETOS E PRECISOS REFERENTES À PESSOA SOB INVESTIGAÇÃO - CONSTITUI ATO EIVADO DE NULIDADE. - A quebra do sigilo inerente aos registros bancários, fiscais e telefônicos, por traduzir medida de caráter excepcional, revela-se incompatível com o ordenamento constitucional, quando fundada em deliberações emanadas de CPI cujo suporte decisório apóia-se em formulações genéricas, destituídas da necessária e específica indicação de causa provável, que se qualifica como pressuposto legitimador da ruptura, por parte do Estado, da esfera de intimidade a todos garantida pela Constituição da República. Precedentes. Doutrina. O CONTROLE JURISDICIONAL DE ABUSOS PRATICADOS POR COMISSÃO PARLAMENTAR DE INQUÉRITO NÃO OFENDE O PRINCÍPIO DA SEPARAÇÃO DE PODERES. - O Supremo Tribunal

Federal, quando intervém para assegurar as franquias constitucionais e para garantir a integridade e a supremacia da Constituição, neutralizando, desse modo, abusos cometidos por Comissão Parlamentar de Inquérito, desempenha, de maneira plenamente legítima, as atribuições que lhe conferiu a própria Carta da República. O regular exercício da função jurisdicional, nesse contexto, porque vocacionado a fazer prevalecer a autoridade da Constituição, não transgride o princípio da separação de poderes. Doutrina. Precedentes. (MS 25668, Relator(a): CELSO DE MELLO, Tribunal Pleno, julgado em 23/03/2006, DJ 04-082006 PP-00027 EMENT VOL-02240-03 PP-00410 RTJ VOL-00200-02 PP00778 RCJ v. 20, n. 129, 2006, p. 55-66) (grifo nosso).

Nesta senda, no Brasil, em última instância - apesar da possibilidade do controle dos atos da administração pública e das leis ordinárias pelos juízes ordinários, cabe ao Supremo Tribunal Federal, na pessoa de seus ministros, proteger a Carta Constitucional, conforme idealizado por Kelsen (1998, p. 189-190), não comportando, assim, infundado esperneio que somente visa demonstrar insatisfação para com as decisões tomadas, sem enfrentar e indicar crimes de responsabilidade cometidos por ministros do Supremo Tribunal Federal.

Diametralmente, a enxurrada de pedidos de impeachment recebidos que visam a figura do Presidente da República - seja Dilma, Temer, Bolsonaro, ou governadores e prefeitos, se limitam, fundamentalmente, a reproduzir que houve crime de 
responsabilidade, sem que se consiga enquadrar algum ilícito capaz de fazer com que o órgão competente processe e julgue conforme determina as Constituições da República e dos Estados e as leis orgânicas dos municípios e do Distrito Federal, resultando em inúmeros contorcionismos hermenêuticos.

Reafirma-se, portanto, que parlamentares e parcela da sociedade civil passou a entender que o impeachment se tornou mecanismo de destituição de mandato eletivo ou a destituição de cargo em razão de descontentamento com determinada decisão que foi tomada, enquanto o referido instituto possui características próprias que denotam a complexidade do processo, as diversas diligências, os desdobramentos sociais da processo, bem como a morosidade que lhe é peculiar tendo em vista a essência inteiramente política do julgamento.

\section{CONSIDERAÇÕES FINAIS}

Desde os primórdios da humanidade o ser humano tem transferido para um outro o direito de se fazer representado. Tal não é fruto de acontecimento recente, pois desde que o ser humano começou a se organizar em grupos, comunidades, até chegar a formar a sociedade como conhecemos hoje ele delegou a alguém ser o chefe da tribo, ser o líder da comunidade, o rei de um determinado local.

Em raríssimas exceções, como na Grécia antiga, é que os caminhos do estado passavam pelo crivo de uma pluralidade de agentes reunidos na ágora. Ali, naquele espaço, em praça pública, se desenvolveu a ideia da democracia direta em que os cidadãos brancos, livres e ricos discutiam os rumos da sociedade ateniense à época exceto as mulheres, as crianças e os escravos. Em contraponto ao modelo ateniense de democracia, os romanos alguns anos adiante recepcionaram $o$ modelo da representatividade a partir do Senado, que era formado pelos anciãos, ou seja, os homens mais velhos, brancos e ricos da sociedade romana. Tal modelo se deu em virtude do alargamento das fronteiras do reino, da República e do Império, que em seu apogeu abrangia quase que toda a Europa, o norte da África e parte da Ásia e a impossibilidade de se juntar, em um mesmo espaço, quando necessário, todos aqueles que poderiam votar.

Com o desenvolvimento e o resgate do modelo representativo após séculos, a sociedade acabou criando mecanismos de que pudesse se valer para quando aquele escolhido como representante já não mais expressasse a vontade do povo - e aqui, em um primeiro momento, estamos falando de nobreza e burguesia. Com o aprimoramento 
das instituições, especialmente na Inglaterra, percebeu-se que um processo burocrático, que trazia para sociedade e para a política em si mais prejuízos do que benefícios, passou-se a adotar no campo do parlamentarismo apenas o voto de desconfiança que acabava por forçar a saída do primeiro-ministro do poder, juntamente com seus ministros, sem a necessidade de se comprovar algum crime, apenas fundado na perda da popularidade e da confiança.

Assim posta a questão, tem-se que o recall, paralelamente ao voto de desconfiança, julga os equívocos políticos, jurídicos e administrativos do representante, assentando-se também na conveniência, mas também na legalidade, pois é mecanismo pelo qual o poder soberano do povo cobra do Governo a prestação de contas (accountability) e se torna instrumento de concretização da participação efetiva na vida democrática, diferentemente do impeachment.

O Brasil, a exemplo dos Estados Unidos, excepcionando a Constituição Imperial de 1824 que trazia instituto de responsabilização similar, consagrou o impeachment como sendo o único meio possível pelo qual um Presidente da República poderia ser retirado do cargo. O tema é de relevante discussão porque a Constituição brasileira, inclusive, consagrou o impeachment como sendo a única forma, além da renúncia e da demissão, de se retirar do cargo um ministro do Supremo Tribunal Federal e o Procurador-Geral da República. A relevância perpassa a ideia de que é um processo político, mas sancionatório e traumático, tendo em vista a necessidade da comprovação do cometimento de crime de responsabilidade.

$\mathrm{E}$, diante disso, o que se percebe é que o referido instituto se tornou carta de baralho que visa tão somente destituir presidentes, governadores, prefeitos, ministros do Supremo Tribunal Federal e ministros de Estado, mas sem a demonstração do crime de responsabilidade cometido ou a promoção de atentado à ordem constitucional. Ora, repisa-se: o impeachment não é instrumento político por meio do qual se destitui autoridades constituídas por simplesmente não gostar delas ou das políticas públicas por elas implementadas. Não se processa ministro do Supremo Tribunal Federal por entender que seu voto, no exercício da jurisdição constitucional, beneficia determinado grupo em detrimento de outro.

Nesse sentido, seguindo os parâmetros históricos e teóricos da doutrina do Controle Constitucional, torna-se nítido o atual protagonismo jurídico desempenhado pelo Supremo Tribunal Federal nas mais variadas facetas e decisões que decidem os rumos da sociedade brasileira que em muito pesam e perpassam pelos caminhos do 
Controle de Constitucionalidade que dão origem a entendimentos e hermenêuticas que afetarão as realidades processuais e jurídicas como um todo.

Registre-se que a evolução da sociedade começa a deixar para trás o paradigma de que os meios de se insurgir contra determinado texto legal ou contra determinada decisão judicial fossem empreendidos por meio das vias legislativas e judiciais cabíveis, pois há de se infirmar que atualmente existem diversas formas para se expressar a insatisfação e tentar forçar uma revisão ou o acuamento de determinada instituição, valendo-se das mídias sociais para inflamar a sociedade e criar uma faísca capaz de acender uma revolta, uma manifestação social a fim de inverter a ordem e pressionar aqueles a quem compete decidir encaminhar o conteúdo decisório para favorecê-los.

Assim, conforme amplamente discorrido, os sucessivos pedidos de impeachment perante o Senado Federal nas hipóteses em que ele autoriza, processa e julga, bem como perante a Câmara Federal, ou diante das Assembleias Legislativas e das Câmaras Municipais, têm sido nos últimos anos o grande causador de backlash ao ser exercido de forma equivocada e destoando-se de seu verdadeiro sentido constitucional, seja a contragosto de grupos conservadores ou progressistas que enxergam no instrumento constitucional não um meio amargo, mas sim a inversão própria da própria ordem constitucional, desestabilizando a segurança jurídica e o próprio Estado Democrático de Direito.

É mais do que certo que o impeachment é remédio amargo, incompatível com a ordem democrática vigente, pois retira do verdadeiro legitimado do poder, o povo, a possibilidade de revogar o mandato concedido no pleito eleitoral de alguém que já não mais representa os interesses públicos, condicionando a manutenção no poder ao cometimento de um crime de responsabilidade e à vontade dos representantes. Demais disso, possui traço negativo para a sociedade, pois traz desconfiança política, incertezas econômicas e sociais.

\section{REFERÊNCIAS}

ABBOUD, Georges. Banalização do impeachment de ministros do STF: backlash à brasileira. ConJur, 2021. Disponível em: <https://www.conjur.com.br/2021-abr01/abboud-banalizacao-impeachment-ministros-stf>. Acesso em: 02 de abr. de 2021.

BONAVIDES, Paulo. Curso de Direito Constitucional. 30ª Ed. São Paulo: Malheiros, 2015. 
BRASIL. Constituição da República Federativa do Brasil, 1988. Disponível em: <http://www.planalto.gov.br/ccivil_03/Constituicao/Constituicao.htm> Acesso em 31 mar. 2021.

BRASIL. Senado Federal. Comissão de Constituição, Justiça e Cidadania. Parecer no . 64, 2017. Disponível em: <https://legis.senado.leg.br/sdleggetter/documento?dm=5366309\&ts=1594024816028\&disposition=inline $>$. Acesso em: 02 abr. 2021.

COUTINHO, Elvis Gibson Leite. Princípio da responsabilidade política. Revista do Instituto do Direito Brasileiro, Lisboa, n. 8, p. 8075-8117, 2013. Disponível em: <http://www.cidp.pt/revistas/ridb/2013/08/2013_08_08075_08117.pdf>. Acesso em: 25 mar. 2021.

CRUZ, Paulo Márcio. Parlamentarismo em estados contemporâneos: os modelos da Inglaterra, de Portugal, da França e da Alemanha. Blumenau: Furb, 1998.

DALLARI, Dalmo de Abreu. Elementos de teoria geral do Estado. 19ª Ed. São Paulo: Saraiva, 2000.

DICEY, Albert Venn. The Privy Council. 1887. New York: Cornell University Library, 2008. Disponível em: <https://newcatalog.library.cornell.edu/catalog/6769482>. Acesso em 02 abr. 2021. FONTELES, Samuel Sales. Direito e Backlash. Salvador: JusPodivm, 2019. KELSEN, Hans. Teoria Pura do Direito. 6 ${ }^{a}$ Ed. São Paulo: Martins Fontes. 1998. MORAES, Alexandre de. Direito Constitucional. 32a Ed. São Paulo: Atlas, 2016. Presidencialismo. $1^{\text {a }}$ Ed. São Paulo: Atlas, 2004.

NATO, Daniel Fernandes. BAUAB, Letícia Filgueira. Os Institutos do Recall Político e do Voto de Desconfiança em Confronto com o Processo Traumático do Impeachment Brasileiro. Revista Jurídica Luso-Brasileira. Lisboa, n. 3, p. 433-464. Disponível em: <http://www.cidp.pt/revistas/rjlb/2019/3/2019_03_0433_0464.pdf>. Acesso em: 03 abr. 2021.

NERY JUNIOR, Nelson. ABBOUD, Georges. Direito Constitucional Brasileiro. $2^{\mathrm{a}}$ Ed. São Paulo: Revista dos Tribunais, 2019.

POST, Robert; SIEGEL, Reva. Roe Rage: Democratic Constitucionalism and Backlash. Harvard Civil Rights-Civil Liberties Law Review, vol. 42, p. 390. Disponível em: $<$ https://law.yale.edu/sites/default/files/documents/pdf/Faculty/Siegel_RoeRageDemocr aticConstitutionalismAndBacklash.pdf>. Acesso em: 27 mar. 2021. 
SILVA, Daniela Romanelli da. Democracia e direitos políticos. São Paulo: Instituto de Direitos Políticos, 2005.

STEPAN, Alfred. Parlamentarismo x presidencialismo no mundo moderno: revisão de um debate atual. Estudos Avançados. São Paulo, v. 4, n. 8, 1990. Disponível em: <http://www.scielo.br/pdf/ea/v4n8/v4n8a07.pdf>. Acesso em 01 abr. 2021. 